\title{
Resistance pattern of Acinetobacter spp. isolated from various clinical samples in and around Kanchipuram
}

\author{
S Senthamarai", S Sivasankari, C Anitha, V Venugopal, SK Amshavathani \\ From First International Science Symposium on HIV and Infectious Diseases (HIV SCIENCE 2012) \\ Chennai, India. 20-22 January 2012
}

\section{Background}

For the past two decades Acinetobacter spp. has been emerged as an important pathogen in various infections. Emergence of multi drug resistance limits the therapeutic option. So this study is aimed to determine the antibiotic resistance pattern of Acinetobacter spp. from various clinical samples.

\section{Methods}

The study included a total of 1516 samples of which 892 were from pus and 624 were from sputum collected from patients at Meenakshi Medical College and Research Institute, Kanchipuram from Nov 2010 to August 2011. Samples were processed and identified according to standard protocol. The Acinetobacter spp. isolates were tested for antibiotic resistance against 16 antibiotics by Kirby Bauer disc diffusion method (CLSI guidelines).

\section{Results}

Out of 1516 samples collected, 50 (3.3\%) Acinetobacter spp. was isolated. Among which $35 / 50(70 \%)$ were from pus, $15 / 50(30 \%)$ were from sputum. All the isolates were found to be $100 \%$ resistant to ampicillin, $76 \%$ resistance to co-trimoxazole cefuraxime and ceftazidime, $64 \%$ to doxycycline. Ciprofloxacin and gentamicin showed $58 \%$ resistance, followed by netilmicin, amikacin and tetracycline with $57 \%, 50 \%$ and $46 \%$ resistance. Ofloxacin, sparfloxacin and levofloxacin showed 33\%, $21 \%$ and $17 \%$ resistance. Least resistance was observed for amoxyclav, ceftriaxone/tazobactam and imipenem with $11 \%, 5 \%$ and $5 \%$ resistance respectively. Out of 50 isolates $31(62 \%)$ were found to be multi drug resistant.

\footnotetext{
* Correspondence: drthamaraithiagu@yahoo.co.in

Dept of Microbiology, Meenakshi Medical College and Research Institute, Kanchipuram, Tamil Nadu, India
}

( 2012 Senthamarai et al; licensee BioMed Central Ltd. This is an Open Access article distributed under the terms of the Creative Commons Attribution License (http://creativecommons.org/licenses/by/2.0), which permits unrestricted use, distribution, and reproduction in any medium, provided the original work is properly cited. and take full advantage of:

- Convenient online submission

- Thorough peer review

- No space constraints or color figure charges

- Immediate publication on acceptance

- Inclusion in PubMed, CAS, Scopus and Google Scholar

- Research which is freely available for redistribution Submit your manuscript at
www.biomedcentral.com/submit C Biomed Central

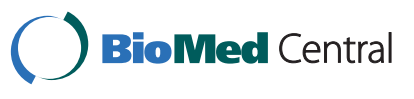

\section{Conclusion} screen and formulate appropriate antibiotic policy for the hospitals and prevent further development and Cite this article as: Senthamarai et al:: Resistance pattern of Acinetobacter spp. isolated from various clinical samples in and around Kanchipuram. BMC Infectious Diseases 2012 12(Suppl 1):P57. 